\title{
An Ecofeminist Reading of NoViolet Bulawayo's We Need New Names
}

\author{
Dr. Salman Mohammed Salama \\ Faculty of Education - English Department \\ Damanhour University - Egypt
}

\begin{abstract}
This paper explores the parallels between the degradation of the environment and the oppression of women in NoViolet Bulawayo's novel We Need New Names. Using the ecofeminist lens, this study investigates the interconnections between environmental deterioration and the oppression of black women in Zimbabwe where Darling, a young black girl leading a miserable existence, has to endure marginalization and humiliation. The novel is simply Darling's fragmented memoir of the violence exercised by the patriarchal authorities in her society over both the environment and women. Darling's story reveals how women bear unbearable burdens in family sustenance that becomes even more difficult with environmental degradation. In the light of these premises, this article offers an ecofeminist reading of Bulawayo's novel with an emphasis on the interconnection between the degradation of the environment and the subordination of black women in the novel.
\end{abstract}

Keywords: NoViolet Bulawayo, Ecofeminism, We Need New Names, Patriarchy, Women, Nature.

\section{Introduction}

NoViolet Bulawayo (12 October 1981- ), pen name of Elizabeth Zandile Tshele, is a Zimbabwean novelist and short story writer who is the first African woman to be shortlisted for the Man Booker Prize. She emigrated to USA, Michigan, when she was eighteen in order to complete higher education, and she got her bachelor's degree in English from Texas A\&M University. Bulawayo also got an MA in English from Southern Methodist University and a Master of Fine Arts in Creative Writing from Cornell University. She wrote two short stories: "Snapshots" published in New Writing from Africa in 2009 and "Hitting Budapest", published in the November/December issue of the Boston Review in 2010. Her debut novel, We Need New Names (2013), won several awards and recognitions such as the second place in the Barnes \& Noble Discover Award for Fiction in 2013, the National Book Foundation '5 Under 35' Fiction Selection in 2013, the Los Angeles Times Book Prize Art Seidenbaum Award for First Fiction in 2013, the Hemingway Foundation/PEN Award in 2014, the Zora Neale Hurston/ Richard Wright Legacy Award for Fiction in 2014, the Etisalat Prize for Literature in 2014 and was shortlisted for the Man Booker Prize. The novel was also declared as one 
of the National Public Radio's Great Reads of the Year for 2013 and one of the New York Times Notable Books of 2013. Bulawayo also received other honors and awards such as the Truman Capote Fellowship in 2010, the Caine Prize for African Writing in 2011, the Finalist for the Guardian First Book Award in 2013 and the Betty Trask Award in 2014. Bulawayo is now a Wallace Stegner Fellow at Stanford University, and she is also a Jones Lecturer in Fiction at the university. In addition, she is one of the trustees of the Writivism Board for promoting African Literature.

Bulawayo returned to Zimbabwe after 13 years only to find her country in a devastating condition since the government had failed to satisfy the basic needs of its citizens. She generally writes about feminist issues faced by black women and she has been brave in criticizing the rule of President Robert Mugabe ${ }^{1}$. She is currently working on a collection of stories portraying the tragedy of AIDS since she lost a brother, a sister and more than twenty people of her relatives because of this disease. We Need New Names, Bulawayo's first novel, narrates the story of Darling, the novel's protagonist and a newcomer in America, who leaves Zimbabwe searching for a better life. The novel generally evokes the bitterness, complexity and anxiety of leaving one's homeland for another country, and it traces Darling's encounters to reinvent herself in a new place. Although she is only ten years old, Darling has to find her way through a precarious and cruel world. In her Zimbabwean homeland, Darling has led a peaceful life before the demolition of her house and her school by paramilitary policemen, but Darling is lucky enough since she has an aunt in America. She immigrates to USA only to find a highly competitive society with limited options for immigrants.

\section{Ecofeminism: A Theoretical Background}

Ecofeminism, a branch of feminism also called ecological feminism, is a combined product of feminism and environmentalism. Ecofeminism theory, which is a combination of the objectives of both women's liberation movement and the ecological movement of the late 1960s, investigates both ecological issues and women's issues as a combined whole. Ecofeminism emerged in the 1970s alongside second-wave feminism declaring a connection between the degradation and exploitation of the environment and the oppression and subordination of women. What distinguishes ecofeminism from other branches of feminism is that it considers challenging the groundless domination of nonhuman nature as an essential feminist issue. Ecofeminism emerged in

${ }^{1}$ Robert Gabriel Mugabe (February 21, 1924, September 6, 2019) is the first prime minister (19801987) and then a president of Zimbabwe (1987- November 21, 2017). He resigned after powerful political and military pressure, and died in Singapore on September 6, 2019. 
a tense context of environmental pollution, ecological crisis, wars, gender inequality, socioeconomic impoverishment, militarism and totalitarianism. The term was first coined by the French writer Francoise d'Eaubonne (1920-2005) in her book, Feminism or Death (Le Feminisme ou la Mort) (1974) in which she urged women to instigate an ecological revolution to save the earth. D'Eaubonne believed that all environmental disasters are created by patriarchal cultures, so she founded the EcologyFeminism (Ecologie-Féminisme) Center in Paris in 1972 and used the term ecofeminisme later in her book. Many other ecofeminist theorists have also pinpointed the intrinsic relationship between the domination of women and the exploitation of nature; King (1983) pinpoints that "the hatred of women and the hatred of nature are intimately connected and mutually reinforcing" (p. 118). Ruether (1994) maintains that ecofeminism "explores how male domination of women and domination of nature are interconnected, both in cultural ideology and in social structures" (p. 2). Glotfelty and Fromm (2009) define ecofeminism as "a theoretical discourse whose theme is the link between the oppression of women and the domination of nature" (p. xxiv). Gaard (2010) defines the term in the following way:

Ecofeminism is a theory that has evolved from various fields of feminist inquiry and activism: peace movements, labor movements, women's health care, and the anti-nuclear, environmental, and animal liberation movements. Drawing on the insights of ecology, feminism, and socialism, ecofeminism's basic premise is that the ideology which authorizes oppressions such as those based on race, class, gender, sexuality, physical abilities, and species is the same ideology which sanctions the oppression of nature. Ecofeminism calls for an end to all oppressions, arguing that no attempt to liberate women (or any other oppressed group) will be successful without an equal attempt to liberate nature (p. 1).

The above mentioned viewpoints offer the fundamental grounding on the domination of both women and the environment in this article. It can be understood from these ecofeminist views that the movement is a combined product of a variety of fields, and its ultimate objective is to liberate women and nature from all forms of oppression. Ecofeminists therefore expose the ways in which male-centered cultures in patriarchal societies exert power over women and their environment.

Ecofeminists suppose that the environment does not only refer to wilderness areas such as hills, mountains, forests, woods, deserts, seas, oceans...etc, but they expand the notion of the environment to include housing, health problems and everything that affects women's lives (Shiva, 2014a). Warren (2010) expounds her view on which issues are 
considered "environmental" and clarifies that the ecofeminist notion of the environment is much wider than the traditional one. Warren maintains:

People of color have infused issues of power, domination, racism, discrimination, distribution of risks and benefits, and inequality and justice into the debate. Lack of housing for the poor and homeless, hazardous working conditions, cancers, and other health effects arising from environmental causes are but a few of the issues that environmental justice activists have brought into the environmental debate when other environmentalists did not consider them to be environmental issues or paid little attention to them (2010, p. 50).

In this way, issues like discrimination, homelessness, racism, epidemics, inequality and hazardous working conditions have all been added to the environmental debate. Moreover, ecofeminists suppose that the environment encompasses all plants, animals and ecosystems which have been unjustifiably dominated and exploited. They simply believe that "Nature is a feminist issue" (Warren, 2000, p. 1).

Warren (2000) states that ecofeminism has grown out of women's political actions, and "it has found diverse expression in the arts, literature and language, science and technology, philosophy and religion, and nongovernmental organizations" (p. xiii). Ecofeminism has been subsequently tackled by numerous scholars in various academic disciplines, and ecofeminist scholars often associate their analysis of ecological issues, such as pollution, deforestation, food shortage and nuclear waste with an understanding of the dilemma of women, children, marginalized groups and people of color. During the late 1970s and early 1980s, the ecofeminist tide rose due to a series of conferences, lectures, seminars and workshops that were held by a group of academic feminists. They sought to demonstrate how feminism and environmentalism might work together to promote respect for women and nature since they are frequently depicted as irrational and chaotic by patriarchal cultures that abuse and manipulate both women and nature. Ecofeminism is also concerned with women movements that support and defend the continuation of life on earth. The American ecofeminist philosopher and historian Carolyn Merchant (2012) mentions several examples that indicate women's efforts to save the degraded environment: the Kenyan women of the Green Belt movement who "plant millions of trees in arid, degraded lands", the Indian women who initiate the Chipko movement ${ }^{2}$

${ }^{2}$ A peaceful ecological movement in which rural Indian women protected trees from being cut down by embracing them. The movement started in the 1970s in Uttarakhand, India. 
"to preserve precious fuel resources for their communities", the Swedish women who "prepare jam from berries sprayed with herbicides and offer a taste to members of parliament: they refuse", the Canadian women who attempt to "obtain signatures opposing uranium processing near their towns" and the American women when they "organize local support to clean up hazardous waste sites" (p. 193). Ecofeminism, thus, results in several ecological movements directed through values and perspectives of women. Actually, women suffer greater harm in the ecological crisis, especially in the third world countries, because of their traditional roles in managing food security and natural resources. Ecofeminist philosophy, therefore, frequently refers the negative consequences environmental degradation might have on women's bodies and minds.

The first collection of essays on ecofeminism titled: Reclaim the Earth: Women Speak Out for Life on Earth was edited by Leonie Caldecott and Stephanie Leland in 1983. This was followed by a multiplicity of influential publications on ecofeminism such as Judith Plant's collection of articles Healing the Wounds: The Promise of Ecofeminism (1989), Andree Collard and Joyce Contrucci's Rape of the Wild: Man's Violence Against Animals and the Earth (1989), Irene Diamond and Gloria Orenstein's Reweaving the World: The Emergence of Ecofeminism (1990), Carol Adams' The Sexual Politics of Meat: A Feminist-Vegetarian Critical Theory (1990). Maria Mies and Vandana Shiva's Ecofeminism (1993), Carol Adams' Ecofeminism and the Sacred (1993), Val Plumwood's Feminism and the Mastery of Nature (1993), Irene Diamond's Fertile Ground: Women, Earth and the Limits of Control (1994), Linda Hogan, Deena Metzger and Brenda Peterson's Intimate Nature: The Bond Between Women and Animals (1997), Greta Gaard's Ecological Politics: Ecofeminists and the Greens (1998), Ivone Gebara's Longing for Running Water: Ecofeminism and Liberation (1999) and Karen J. Warren's Ecofeminist Philosophy: A Western Perspective on What It Is and Why It Matters (2000). These publications generally explore the connections between women and nature in religion, culture and literature, emphasize the parallels between the oppression of nature and the oppression of women, address issues such as gender equality and environmental preservation and argue against dominance of patriarchal values. Most ecofeminists usually come out with a key conclusion; that is humans' need to manipulate the environment is similar to men's need to manipulate women.

In the United States, ecofeminism grew thanks to the conferences and courses conducted by the feminist theorist Ynestra King at the Institute for Social Ecology in Vermont. King considers ecofeminism as the third wave of feminism, and her article "What Is Ecofeminism?" (1987) has 
greatly advanced the concept of ecofeminism in philosophical scope. In this article, King criticizes the ways in which the American belief systems permit the abusive use of the environment and the further repression of women. Ecofeminism became a movement in the late 1970s and the 1980s due to several conferences, workshop and events such as: the 1974 conference entitled "Woman and Environment" held in Berkeley, California, and organized by geographers Lisa Watkins and Sandra Marburg, a major conference titled "Women and Life on Earth: Ecofeminism in the 80s", held by King and other feminists, the 1980 Women's Pentagon Action in which about two thousand women surrounded the Pentagon protesting against nuclear weapons development, the 1981 West Coast ecofeminist conference held at Sonoma State University, the 1987 conference on "Ecofeminist Perspectives: Culture, Nature, Theory" organized by Gloria Orenstein and Irene Diamond at the University of Southern California, the 1991 World Women's Congress for a Healthy Planet held by Women, Environment, and Development Organization (WEDO) in Miami in 1991 in preparation for the 1992 Rio de Janeiro Earth Summit, and the 1995 conference on "Ecofeminist Perspectives" held at Ohio State University. Ecofeminists thenceforth engage in events related to women's connections to the environment

Other notable ecofeminists include the American feminist scholar and Catholic theologian Rosemary R. Ruether who maintains that all women must strive to put an end to the exploitation of the environment if they wish to achieve their own liberation. Ruether asserts that feminists and environmentalists must collaborate against patriarchal and male-centered cultures (Ruether, 2002b). She further highlights the relationship between the subordination of women by patriarchal cultures and environmental degradation affirming that there is neither liberation for women nor solution for environmental problems in a society which is governed by patriarchal logic of domination. Therefore, Ruether urges women to unite the objectives of the feminist movement with the demands of the environmental movement "to envision a radical reshaping of the basic socioeconomic relations and the underlying values of this society" (2002a, p. 204). During the late 1980s and the 1990s, ecofeminism spread rapidly to other countries and ecofeminists in England, Germany, Sweden, Brazil, Australia, India and Africa started defending the continuation of life on earth and arguing against the damage done to both women and the environment through conferences, workshops, political actions, books, articles and anthologies. 
The ecofeminist philosopher Val Plumwood (2002) maintains that ecofeminism is essentially a product of radical feminism, cultural feminism and socialist feminism. Ecofeminism is greatly impacted by radical feminism which highlights the preeminence of women's reproductive function. Cultural Feminism emphasizes that women can play a vital role in fighting environmental pollution while socialist feminism has induced Ecofeminism to pay more attention to economic analysis instead of focusing only on cultural analysis. In addition, a noteworthy feature of ecofeminist theory is that it focuses on ecological issues related to Deep Ecology ${ }^{3}$ and Social Ecology ${ }^{4}$. Plumwood (2001) confirms that nature/culture dualism is a product of western cultural history and calls it "the foundational delusion of the West" and considers it is as a "dangerous doctrine, strongly implicated in the environmental crisis" (p. 26). Plumwood (2002) also clarifies that not only nature and culture are comprehended dualistically in western culture, but also a set of interrelated dualisms pervade western culture and permeate its entire conceptual system. The main dualisms highlighted by Plumwood include: mind/body, male/female, culture/nature, reason/nature, civilized/primitive, master/slave, human/nature and human/animal. The first category of each dualism denotes the dominant or superior, whereas the second part of each dualism represents the dominated or inferior. Plumwood (2002) calls this androcentric dualism "the logic of colonization" (p. 41), and argues that the western model of human/nature dualism results from a "denied dependency on a subordinated other" ( $\mathrm{p}$. 41). This denied relationship of domination/subordination results in a certain hierarchy that shapes the identity of both the dominating and the dominated in order to lend legitimacy to these androcentric dualisms and make them appear as natural.

With regard to woman/nature connections and how to improve them, Merchant (2012) highlights three dimensions of ecofeminism: liberal, cultural and social. According to Merchant, these categories indicate how women around the world have made connections to the environment and represent three different ecofeminist perspectives toward improving the relationship between humans and their environment. Liberal ecofeminism, in Merchant's words, aims to "alter human relations with nature from within existing structures of governance through the passage of new laws and regulations" (p. 197). Liberal ecofeminists assume that the domineering patriarchal cultures equate women with nature so as to

\footnotetext{
${ }^{3}$ An environmental philosophy and movement which believes that humans must not value nature only for its usefulness to them, but they must recognize that nature has an intrinsic value.

${ }^{4} \mathrm{~A}$ social theory founded by Murray Bookchin. It believes that environmental degradation occurs due to the injustice and hierarchy that characterize modern capitalist society.
} 
exploit both of them; consequently, liberal ecofeminists endeavor to terminate the patriarchal associations between women and nature via issuing new laws and regulations to fight the unjustified exploitation of nature and the subordination of women. Cultural (also Spiritual) ecofeminism, which flourished during the 1980s, "analyzes environmental problems from within a critique of patriarchy and offers alternatives that could liberate both women and nature" (p. 197), and it also "celebrates the relationship between women and nature through the revival of ancient rituals centered on goddess worship, the moon, animals, and the female reproductive system" (p. 202). Cultural ecofeminists believe that women are more sensitive to the patriarchal unjustified degradation of nature since they have an intimate relationship with the environment such as their gender and biological roles as provider of food, family nurturer, pregnancy and lactation. Social (also Materialist, Marxist or Socialist) ecofeminists found their argument on capitalist patriarchy and "they ask how patriarchal relations of reproduction reveal the domination of women by men, and how capitalist relations of production reveal the domination of nature by men" (p. 197). Social ecofeminists consider the connections between property, power and labor as the source of domination over women and nature, so they seek to eradicate all patriarchal social and economic hierarchies and advocate women liberation. Apparently, cultural ecofeminism seems to divulge more deeply into the interconnections between woman and nature, whereas social and socialist ecofeminism provide a methodical critique of patriarchal domination. Although these ecofeminist approaches may differ with regard to the fundamental objective of ecofeminist movement, they all share the same ecofeminist aspiration to improve the quality of life for all the inhabitants on the planet.

According to ecofeminist theory, the relationship between women and nature is based on one of three ecofeminist claims. Eaton and Lorentzen (2003) pinpoint three main philosophical claims that concern ecofeminism and are central to ecofeminist analysis; these are the empirical claim, the conceptual (cultural/symbolic) claim, and the epistemological claim. The empirical claim, in Eaton and Lorentzen's words, is that "environmental problems disproportionately affect women in most parts of the world" (p. 2). The conceptual (cultural/symbolic) claim is that "women and nature are connected conceptually and symbolically in Euro-western worldviews" (p. 2). The epistemological claim is that "women possess greater knowledge and expertise that could prove useful in finding solutions to pressing environmental problems" (p. 3 ). The ecofeminist empirical claim is based on the fact that women are 
the greatest sufferers of environmental degradation. The feminist geographer and global policy expert Joni Seager elucidates that it is an established fact that women are the worst victims of environmental destruction. The poorer they are, the greater is their burden (Seager, 2019). As a result of environmental deterioration and ecological deprivation, women bear intolerable burdens in family sustenance that becomes increasingly difficult with environmental deterioration. The conceptual (cultural/symbolic) claim of ecofeminism suggests that women and nature are connected symbolically and culturally in several ways. Some ecofeminists believe that patriarchal cultures identify women with emotions, sexuality, femininity, materiality, or nature and; and men with reason, masculinity the supernatural or heaven. Eaton and Lorentzen maintain that "religion, philosophy, science, and cultural symbols reinforce this worldview, making male power over both women and nature appears 'natural' and thus justified" (2003, p. 2). The epistemological claim of ecofeminism implies that women possess better knowledge which is useful in finding solutions to ecological problems. Eaton and Lorentzen confirm that women have better agricultural knowledge than men; therefore ecofeminists believe that "women are in a good position to aid in creating new practical and intellectual ecological paradigms" since they are "best equipped to address local environmental problems" (2003, p. 3). In this way, ecofeminists believe that women are closer to and more familiar with nature than men since they are more caring, nonaggressive and earth-sensitive humans.

It is true that all ecofeminists believe that there are interconnections in the way women and their environment are dominated by patriarchal culture, but they differ regarding the nature of those interconnections. Warren (2000) highlights ten types of women-nature interconnections: "historical (typically causal), conceptual, empirical, socioeconomic, linguistic, symbolic and literary, spiritual and religious, epistemological, political, and ethical interconnections" (p. 21). With regard to the historical interconnections, Warren believes that the "historical pervasiveness of patriarchal domination of women and nature has led some ecofeminists to suggest that androcentrisrn (male-centered thinking) is the root cause of environmental destruction" (p. 22). Some ecofeminists suppose that such patterns of patriarchal domination start with the invasion of IndoEuropean societies by nomadic tribes while others regard those forms of domination as resulting from the cultural and scientific changes that have occurred in recent times. Ecofeminists assert that, in ancient times before the nomadic invasion, societies were characterized by nurturing relationships between humans and their environment, and the earth was often associated with a nurturing mother or a kind beneficent girl. As 
regards the conceptual interconnections, Warren identifies them as "logic of domination" (p. 24), and sees them in the "role rationalism plays in the domination of women and nonhuman nature" (p. 24). She also states that they can be located in any patriarchal conceptual framework or in sexgender differences, as some other ecofeminists believe. After all, Warren proposes that women's social bodily experiences such as childbearing and child rearing "situate women differently with respect to nonhuman nature than men" (p. 24). This role of females in pregnancy and child raising is frequently compared to the role of nature in society. Empirical interconnections, in Warren's viewpoint, refer to the experiential data which "link women, people of color, the underclass, and children with environmental destruction" (p. 25). This includes the ecological crises and the practices of First World development policies that hinder women from supporting themselves and their families. Socioeconomic interconnections, in Warren's words, exist between "the exploitation of women, women's bodies and women's labor, and the exploitation of nature" (p. 25). It is noteworthy that Warren is much influenced in her analysis of socioeconomic interconnections by the Indian environmental activist and ecofeminist Vandana Shiva who has coined the term maldevelopment to describe "a paradigm that sees all work that does not produce profits and capital as non-or unproductive work" (warren, 2000, p. 26). Shiva (2016) believes that the paradigm of maldevelopment fostered by industrial capitalism sees women in peasant and tribal societies as unproductive and hinders their ability to sustain their families because, according to this paradigm, production "takes place only when mediated by technologies for commodity production, even when such technologies destroy life" (p, 4). Linguistic interconnections, as clarified by Warren, indicate the way women are animalized in several cultures "where animals are seen as inferior to humans, thereby reinforces and authorizes women's inferior status" (p. 27). Male-centered societies frequently refer to women as cats, pussycats, bunnies, foxes, chicks, bitches, old hens, queen bees, cheetahs...etc. This is the way language is used in patriarchal cultures to feminize nature and view women as inferior and subordinate. Symbolic and literary interconnections denote some symbolic patterns in culture and literature that link women and nature. This is simply the "new genre of literary analysis called ecofeminist literary criticism" (Warren, 2000, p. 29). Ecofeminist literary criticism critiques any domination exercised over women and nature or any attempt to degrade or abuse both of them. Spiritual and religious interconnections allude to the destructive hierarchy that exists at the heart of Judeo-Christian and Western tradition. Warren maintains that "in this 
hierarchical pyramid of dominance and status, the higher up one goes, the closer one is to all that is spiritual and superior" (p. 30). Ecofeminists often investigate the alleged spiritual inferiority of women in JudeoChristian and Western tradition in order to uncover the patriarchal origin of these myths which always put males up and females down. Epistemological interconnections stand for the ecofeminist belief that listening to the marginalized groups can be considered as the first step toward a better understanding of environmental problems. Warren confirms that through "listening to the perspectives of those at the bottom of social hierarchies", we can "see alternative ways of viewing an environmental problem, analyzing data, or theorizing about women-other human Others-nature interconnections" (pp. 33-34). Warren then exemplifies epistemological interconnections with the Chipko movement in which local Indian women's knowledge provides a helpful insight into understanding ecological problems to those from different cultures. Political interconnections, as explained by Warren, mean that "ecofeminism has always been a grassroots political movement motivated by pressing pragmatic concerns" (p. 35). Ecofeminist activists always focus on the exploitation of women and their environment especially in the Third World, criticize the political systems that constrain women's productive roles, and call for increasing women's political and socioeconomic power in order to protect the environment. Ecofeminist politics has its roots in the type of feminism that inspires ecofeminists; this might be postcolonial feminism, radical feminism, Marxist feminism or socialist feminism. Ethical interconnections refer to the ecofeminist view that ecofeminist philosophy is much concerned with environmental ethics. Ecofeminist environmental ethics aim at developing non androcentric theories about the environment, and Warren maintains that "ecofeminist philosophers argue that the interconnections among the conceptualizations and treatment of women, other subordinated humans, animals, and (the rest of) nature require a feminist ethical analysis and response" (p. 37). These are the ten types of women-other human Othernature interconnections discussed by ecofeminists. The term Ecofeminism might be new, but violence against women and nature and women's efforts to save their families, livelihood and communities are as old as patriarchy. This argument finds resonance with the aim of this study which is to provide as ecofeminist reading of Bulawayo's We Need New Names. Actually, I did my best to provide a theoretical background of ecofeminism in this article. However, I still admit that I cannot summarize decades of ecofeminist argument into one article (I wish).

\section{An Ecofeminist Reading of We Need New Names}


This ecofeminist reading of Bulawayo's We Need New Names explores the parallels between the degradation of Zimbabwean environment and the subordination of the country's black females. In her debut novel, Bulawayo illustrates how culture and nature are intrinsically linked in a way that the harm done to the environment parallels the harm oppressive cultures exercise over women. The symbolic and metaphorical representations of nature in the text reveal how Bulawayo's female characters connect with varied forms of the degraded Zimbabwean environment. Actually, I have found Zimbabwe, in particular, a fertile land for my ecofeminist project. Sithembiso G. G. Nyoni, a Zimbabwean politician and a former Minister of Small and Medium Enterprises Development, confirms that Zimbabwean women suffer greatly as a result of Africa's economic crisis and the excessive exploitation of natural resources. Nyoni avers that "the adverse effects of Africa's current socalled economic crisis and external debt... fall disproportionately on women and make their problems ever more acute" (as cited in Merchant, 2012, p. 215). In addition, the Zimbabwean activist and ecofeminist Kathini Maloba, argues that many Zimbabwean women "suffer loss from poor crops on marginal soils, lack of firewood, polluted water, poor sanitation, and housing shortages. Women have suffered miscarriages from the use of chemical fertilizers and pesticides" (as cited in Merchant, 2012, p. 216). I have selected Bulawayo's We Need New Names for this ecofeminist study since it clarifies the serious damage in the relationship between humans and their environment, focuses on some environmental themes such as maldevelopment, resource grabbing and immigration and redefines the Zimbabwean environment by connecting social and political injustices with environmental issues.

Narrated in the first person by Darling Nonkululeko Nkala; a ten-year-old girl trying to survive the confusion, violence and poverty prevailing her country under the leadership of an oppressive political regime, the novel provides a trenchant criticism of the deteriorated life conditions in a Zimbabwean shantytown called Paradise where young Darling and her friends, Bastard, Godknows, Stina, Sbho, and Chipo, witness violent events. Darling's story provides a trenchant criticism of the Zimbabwean environmental degradation and its disastrous impacts on black women. Darling comments on the wretched conditions of black females in her community saying: "We are tired. Our voices are hoarse. Our faces are drained... Our clothes are bloodied" (p. 143). The novel's beginning reveals how such degradation of the Zimbabwean environment along with the displacement of Bulawayo's female characters deprive them of their means of survival due to the callous exploitation of the Zimbabwean 
natural resources in the name of development. To be precise, the maldevelopment conducted by the patriarchal Zimbabwean authorities have exhausted the country's natural resources, and, as the novel progresses, it becomes clear that Zimbabwean women and children are the greatest sufferers. Darling and her mother have lived in Paradise after the demolition of their house by the government. Operation Murambatsvina, also known as Operation Restore Order, was a Zimbabwean government cleanup campaign that destroyed thousands of houses and stores in slum areas and shantytowns across the country by force; the literal translation of murambatsvina is "getting rid of the filth". The campaign began in 2005 under Mugabe's rule and displaced at least 700,000 people and seriously affected around 2.4 million people. Bulawayo portrays the campaign as a "tsunami walks on water... it came out of the water and left all those people dead in that other country" (pp. 67-68). Innocent ten-year-old Darling has not comprehended any of this, only that their house is gone, so her family moves to the shantytown of Paradise.

Homelessness is one of the main environmental topics that concern ecofeminists, and the cruel demolishing of houses and other facilities in Operation Murambatsvina, as shown in We Need New Names, demonstrates a traumatic form of environmental degradation. Bulawayo argues indirectly with such deliberate degradation of Zimbabwean environment through what is said on the tongue of her girl-child protagonist. Darling narrates appalling memories of the cruelties during Operation Murambatsvina saying: "The men knock down our house and Ncane's house and Josephat's house and Bongi's house and Sibo's house and many houses" (p. 60). After the demolition of all houses and facilities is over, the scene is one of utter destruction and annihilation. Darling recounts that "when the bulldozers finally leave, everything is broken, everything is smashed, everything is wrecked. It is sad faces everywhere, choking dust everywhere, broken walls and bricks everywhere, tears on people's faces everywhere" (p. 66). This monstrous operation devastates both women and children psychologically and emotionally and leaves them homeless and vulnerable. This calls to mind what is said by Shiva (2014b): "the culturally-rooted tribal is made physically homeless by being uprooted from the soil of her/his ancestors" (p. 98). More specifically, the environment that sustains Bulawayo's black females is disrupted because of such an atrocious campaign that displaces Darling and thousands of other Zimbabwean black females. When the interconnectivity between Darling's community and their environment is interrupted, their lives begin to collapse. Darling complains: "We didn't always live in this tin, though. Before, we had a home and everything and 
we were happy. It was a real house made of bricks, with a kitchen, sitting room, and two bedrooms" (p. 62). The androcentric hierarchy and the patriarchal conceptual framework that dominate black females' lives in Darling's community are undoubtedly responsible for this severe violation enacted against women and children. Darling registers what has occurred with Mai Tari and Nomviyo in order to demonstrate the amount of devastation caused by this vicious Operation. Darling narrates:

When they get to Mai Tari's house she throws herself in front of a bulldozer and says, Kwete! You'll have to bulldoze me first before I see my house go down... One ugly policeman points a gun to her head to make her move and she says, Kill me, kill me now, for you have no shame, you could even kill your own mother and eat her up... The policeman does not kill Mai Tari, he only hits her with a gun on the head... Blood gushes from Mai Tari's head and turns the policeman's boots red-red (p. 66).

More pitiful is Nomviyo who has been outside the town and left her son Freedom sleeping in the house:

Nomviyo comes running from the bus stop in her red high-heeled shoes, because she is just returning from town. She sees all the broken houses and she throws all her groceries and bags down, screaming, My son, my son!...Then they are helping her dig through the broken slabs and then Makubongwe appears carrying Freedom, and his small body is so limp and covered in dust you think it's just a thing and not a baby (p. 67).

Poor Nomviyo throws herself on the ground and keeps screaming, weeping, beating the earth and tearing at her clothes until somebody covers her with a blanket and carries her away. This patriarchal violence threatens the harmony between human and non-human nature in Zimbabwe as it deprives black women from their shelter and the resources needed for their livelihoods. This is actually a reminder of the ecofeminist empirical claim that women are the worst victims of environmental destruction. Moreover, it brings to mind the ecofeminist historical interconnections between the domination of nature and the subordination of women. The historical pervasiveness of patriarchal domination of women and nature in Zimbabwean culture has led the male-centered authorities to instigate such environmental destruction regardless of its disastrous effects on women and children. There are no longer nurturing relationships between humans and nonhuman nature, and the earth is no longer a kind beneficent girl in Zimbabwe. Godknows later comments on the deteriorated conditions of the environment in the aftermath of Operation Murambatsvina saying: "There is nothing but 
trees and dry grass and brown earth and Fambeki ${ }^{5}$ and emptiness" (p. 69). Here, the "dry grass and brown earth" symbolizes the overwhelmed and distressed state of both women and the environment after Operation Murambatsvina.

Amid this destruction, Darling's narration establishes the connections between this degradation of the Zimbabwean environment and the oppression of the country's black females. Ironically, despite the apparent poverty and homelessness, the Zimbabwean government hires a Chinese company to build a big mall; Shanghai is a shopping mall under construction. The Chinese have come with their giant machines; "machines hoist things in their terrible jaws, machines maul the earth, machines grind rocks, machines belch clouds of smoke, machines iron the ground" (p. 42). Darling conceives China as a red devil, a dragon and a ferocious beast. This project results in more erosion of environmental resources, more homelessness, more poverty and more degradation of nonhuman nature. Stina asks a Chinese worker: "What are you building? A school? Flats? A clinic?", and the man replies: "We build you big big mall. All nice shops inside, Gucci, Louis Vuitton, Versace, and so on" (p. 48). Of course, none of the poor and homeless women and children has the money to purchase anything from these "nice shops". Darling comments on such a paradoxical situation saying: "If it weren't for the noisy machines, the Chinese would hear us telling them to leave our country and go and build wherever they come from, that we don't need their kaka mall, that they are not even our friends" (p. 47). Darling and her friends are aware that the whole project is useless to their poor and homeless community, and they are also aware that the Chinese have just come to exploit their local environment and natural resources. Even the Zimbabwean men are also humiliated and exploited by the Chinese; while the latter wear "orange uniforms and yellow helmets", the black men work in old and regular clothes such as "torn T-shirts, vests, shorts, trousers cut at the knees, overalls, flip-flops, tennis shoes" (p. 42). Darling describes the miserable black men at the construction site saying "they look like they've been playing in dirt all their lives-it's all over their bodies, their clothes, their hair" (p. 44). It seems that, in Bulawayo's novel, racism, patriarchy and colonialism are inextricably linked to the environment.

Thus, in the name of development and economic reform, both Zimbabwean women and their environment have been unjustifiably exploited and degraded. Bulawayo's cultural ecofeminist view is that Darling and the other black females are more sensitive to such a

${ }^{5}$ It is a popular mountain, New Lobengula, Bulawayo, Zimbabwe. 
patriarchal degradation of the Zimbabwean environment than black males. Operation Murambatsvina's main target, as announced by the Zimbabwean government, was to restore order and eliminate poverty. However, the campaign resulted in massive environmental destruction and more poverty as shown in Darling's tin house and her family's bed which is made up of "plastic and chicken's and duck's feathers and old pieces of cloth" (p. 63). This impoverished environment is even worsened by the food shortage crisis that harvest more lives in Paradise. In this shantytown, Darling, her mother and other black females are all deprived of their basic needs such as food and shelter and they become the most vulnerable victims of such a so-called dirt-removing operation. Darling frequently pictures the poverty and violence that prevail the shantytown of Paradise due to Operation Murambatsvina. The novel's first chapter, "Hitting Budapest", portrays an innocent picture of Darling and her friends who travel to nearby cities to steal guavas from the prosperous district of Budapest, where the wealthy white minorities live, in order to satisfy their hunger. Budapest has "big houses with satellite dishes on the roofs and neat graveled yards or trimmed lawns, and the tall fences and the Durawalls and the flowers and the big trees heavy with fruit" (p. 4). The logic of racism and domination is demonstrated through the environment of Budapest; the Durawalls ensure the security of the white minorities in their walled neighborhoods, and they are also clear evidence of the segregated urban hierarchy in Zimbabwe. Sbho wishes to live in Budapest, but she is reminded by Bastard that "Budapest is not a kaka toilet for anybody to just walk in, it's not like Paradise" (p. 14). Darling says that it is the fruit that gives the children courage to go there; otherwise they dare not be there. Darling relates: "I keep expecting the clean streets to spit and tell us to go back where we came from" (p. 4). The wide discrepancy between Paradise and Budapest reflects the ecological deprivation and miserable conditions of the blacks compared with the privileged white community. Conversely, Darling describes the miserable living conditions in Paradise saying: "We pass tiny shack after tiny shack crammed together like hot loaves of bread... a broken bottle here, a pile of junk over there, a brownish puddle of something here, a disemboweled watermelon there" (p. 26). In such a degraded environment, Darling and her friends frequently face incomprehensible violent deeds against women. After returning from Budapest, the children become so terrified on finding the body of a murdered woman hanging in a tree. Bastard suggests stealing her shoes to buy a loaf of bread, and the children laugh out of horror; not out of happiness. I do not believe that such frequently-witnessed violence becomes familiar to Darling and her 
friends in the same way as televised scenes, but I believe that they are too young to comprehend the depth of such brutality.

The unjustified exploitation of the poverty stricken environment of Paradise parallels the severe abuse of the town's black females as perceived through the spread of sexual assaults. The opening scene of the novel depicts the abuse enforced upon Zimbabwean women by their patriarchal culture as shown through the rape of Chipo; one of Darling's preteen friends. Darling comments on her playing and running with her ten-year-old friends through the town saying that Chipo "used to outrun everybody in all of Paradise but not anymore because somebody made her pregnant" (p. 2). From time to time, the children have to "stop once for Chipo to sit down because of her stomach; sometimes when it gets painful she has to rest it" (p. 2). A barefoot woman asks Chipo about her age, but the poor girl who is eleven and pregnant does not seem to understand the question. Chipo's ingenuousness becomes also clear when she avoids talking or commenting about that sexual assault because of her feeling of shame and because she is unable to articulate what has happened to her. The innocent children think that they have to get rid of Chipo's baby in order to save her, so they plan to perform a coat-hanger abortion for Chipo in the forest because her stomach, her pregnancy, makes it hard for them to play. However, when Forgiveness asks Chipo to pull off her shorts, she pathetically refuses and panics as she has been gravely traumatized by the sexual assault. Chipo finally narrates how she is raped by her grandfather at the age of eleven saying: "He did that, my grandfather... he got on me and pinned me down like that and he clamped a hand over my mouth and was heavy like a mountain" (p. 41). According to the patriarchal oppressive framework that dominates both nature and women in Paradise, Chipo must be silenced and her subsequent pregnancy must not be talked about. They regard rape as normal and deny Chipo's emotional trauma and the "look of pain" in her eyes (p. 41). After being raped, Chipo loses the ability to talk. I believe that Chipo's loss of oracy signifies her vulnerability, her powerlessness and her incapability of self-definition. It also parallels the unprotected Zimbabwean environment which is vulnerable to unjustified exploitation by the same patriarchal culture.

The degradation of Zimbabwean females and their environment is also evident when Darling and her friends peep into a tent at the construction site to see what is inside. The children notice "two black girls in skinny jeans and weaves and heels" getting out of the tent. They "twist past the groups of men who stop working and stare at the girls until they eventually get out of Shanghai and disappear behind the bend near the main road" (p. 45). The children learn that the two black girls provide 
sexual favors to the Chinese workers in order to eat and survive. The scene is an echo of Warren's conceptual interconnections between the degradation of both nature and women since the Chinese exploit both the black girls' bodies and their environment. Both the two black girls and their environment are exploited by the oppressive patriarchal system, and it seems that Darling and her friends are aware that environmental degradation in Zimbabwe also implies the subordination of its black females. Commenting on rape and sexual assaults, Warren (2000) maintains that "probably no behavior of domination is more symptomatic and symbolic of patriarchy than rape" (p. 208). Chipo's rape, the sexual abuse of black females and Operation Murambatsvina are all typical examples of the patriarchal domination exercised over women and nature in We Need New Names.

The novel also portrays a Zimbabwean context thick with social problems such as migrant workers, HIV/AIDS, racism and food shortage. All these social problems have damaging negative impacts on women and children in particular. Darling's father leaves for South Africa after their home is bulldozed, and he returns later to Paradise too sick to work; he is ravaged by HIV/AIDS after living in South Africa and Darling must take care of him now. His body becomes so depleted; he looks like "dry wood" and his eyes are "sunken" as if "he has swallowed the sun" (p. 103). Darling says:

Father comes home after many years of forgetting us, of not sending us money, of not loving us, not visiting us, not anything us, and parks in the shack, unable to move, unable to talk properly, unable to anything, vomiting and vomiting (p. 89).

Public health is one of the main environmental concerns in Bulawayo's novel. Shiva (2014a) considers AIDS as "an ecological collapse" and looks at it as "a phenomenon embedded in, and inseparable from other social realities" (p. 10). Shiva maintains that "just as the number of people being infected by the AIDS virus rises each day, so ecosystems that took thousands of years to evolve are being fragmented and degraded in one human generation" (2014a, p. 10). Thus, the spread of AIDS in Darling's community is a form of environmental degradation, and Darling's father's deteriorated health parallels the dysfunctional and degraded state of Paradise's environment. Darling and her mother decide to keep his sickness a secret, and Darling takes over the responsibility to nurse him. Darling feels growing hatred towards her father as his illness forbids her from playing with her friends; she says: "I'm hating him for making me stop my life like this. In my head I'm thinking, Die. Die now so I can go play with my friends, die now because this is not fair. Die die 
die. Die" (p. 96). Darling's father's conception of family responsibilities and women is part and parcel of the destructive androcentric hierarchy created by the domineering male-biased culture. His negligence and inferiorization of his family result from the prevailing patriarchal conceptual framework which justifies the subordination and oppression of women. This brings to mind the hierarchical androcentric dualisms male/female and mind/body highlighted by Plumwood (2002). I believe that Bulawayo's ecofeminist novel challenges such logic of domination that considers men as superior and women and nature as inferior. We Need New Names exposes these patriarchal oppressive frameworks which authorize the twin exploitation of both women and nature in the novel.

Racism and discrimination are also among the social illnesses that are infused into Bulawayo's ecofeminist debate. We Need New Names explores the interconnections between race, gender and class, and this is clear when Darling hopes, like many people in Zimbabwe, to move to America since her country is suffering from a brutal and oppressive government. Darling moves to America to join Aunt Fostalina, but she maintains close connections to her family and friends in Zimbabwe. Upon her arrival, she is confronted with the American reality which clashes with her dreams of America. It is a strange land where black people do not belong; "they will have to sit on one buttock because they must not sit comfortably lest they be asked to rise and leave" (p. 146). In the United States, Darling faces cultural misunderstandings, sense of loss, violence, nostalgia, and confusion when she assimilates. As an immigrant in a foreign and often hostile land, Darling realizes that, in a different culture, you cannot hide yourself permanently. Unlike Darling, Aunt Fostalina strives for assimilation and wears long white dresses in American weddings. In the first half of the novel, Darling's perspective is limited by her young age, whereas in the second, it is limited by her newness to the American scene. In Michigan, Darling realizes that adolescence and displacement have something in common; the growing pain as she comprehend more and more how you do not belong. Again, the inextricable link between human and nonhuman nature is obvious when Darling comments on the conditions of blacks in America saying:

Leaving their mothers and fathers and children behind, leaving their umbilical cords underneath the soil, leaving the bones of their ancestors in the earth, leaving everything that makes them who and what they are, leaving because it is no longer possible to stay. They will never be the same again because you just cannot be the same once you leave behind who and what you are, you just cannot be the same (p. 146). 
The unwelcoming American environment is exemplified in the freezing snow which is like "a greedy monster" that "has swallowed everything" (p. 148). From an ecofeminist perspective, the American degradation and domination of black immigrants is manifested in the freezing snow that symbolizes how people think and act toward immigrants. In spite of being young, Darling starts doing menial labor jobs to support her aunt. Her homesickness overwhelms her especially when she knows that, as an immigrant, she will not be able to return to America if she leaves and therefore feels as a prisoner in her new country. Even in America, Darling is victimized once again and she "grew restless and cursed America for being the greedy monster that swallowed their children, swallowed the sons and daughters of other lands and refused to spit them out" (p. 237). Bastard tells Darling how black people like aunt Fostalina are humiliated in America in menial labor jobs; "cleaning kaka off some wrinkled old man who can't do anything for himself" (p. 15). Darling's marginalization in America echoes the ecofeminist dualisms of master/slave and civilized/primitive which are a product of western cultural history and runs through its entire conceptual system. Through writing We Need New Names, Bulawayo seeks to eliminate such dualisms with their denied dependency on a subordinated other.

Nature in We Need New Names is feminine and therapeutic, and women are frequently viewed as nurturing and close to nature. The role played by MotherLove and other black women in the aftermath of Operation Murambatsvina demonstrates and reinforces the epistemological claim of ecofeminism that women possess better knowledge while dealing with ecological problems due to their caring, nonaggressive and earth-sensitive natures. In one of Darling's bad dreams, she hears MotherLove singing. "Nobody ever sings like that in Paradise, voice swinging like ripe fruit you can pick and put in your mouth and taste its sweetness" (p. 68). By naturalizing MotherLove's voice, Bulawayo seeks to emphasize the interconnections between women and nature. After Operation Murambatsvina, Darling's community leads a very miserable existence; they live tin shack dwellings and lack education, health facilities and food. It is women's knowledge and tenderness that keep the community surviving. Men pretend to be strong in front of women and children, but while being alone, "they fell apart like crumbling towers and wept with the wretched grief of forgotten concubines" (p. 76). It is women who "gently rose from the hearths, beat dust off their skirts, and planted themselves like rocks in front of their men and children and shacks, and only then did all appear almost tolerable" (p. 77). It is MotherLove, as a symbol of resistance, who sustains people in times of need; she "appeared 
with enormous barrels in which to brew a potent liquor that would make people forget. She also appeared with songs in her throat and the most colourful dresses in her sacks" (p. 76). It is also MotherLove who rescues Chipo from her friends in the forest upon their attempt to save Chipo from death by getting rid of her stomach; therefore MotherLove embodies authority over nature and children. Darling's mother, too, is badly affected by her husband's recklessness and his subsequent sickness. Darling describes her saying "Mother's eyes are tired and her face is tired; ever since Father came she has been busy doing things for himwatching him and cooking for him and feeding him and changing him and worrying over him" (p. 97). In addition to the inhuman life conditions in Paradise, Darling's mother strives to sustain her family and her sick husband. Thus, nature becomes a feminist issue since women bear intolerable burdens in family sustenance that becomes increasingly difficult with the environmental deterioration in the aftermath of Operation Murambatsvina.

The interconnectedness between women and nature is also demonstrated when the children use the forest as a functional emergency room for Chipo's abortion. The forest provides Darling and her friends with purpose and meaning after the destruction caused by Operation Murambatsvina, and it also helps them to invent their own alternative world in which they create new names for themselves in order to escape their oppressive patriarchal culture. The children call the forest ER, emergency room, and they create new names for themselves in order to do the abortion properly. Darling says: "In order to do this right, we need new names. I am Dr. Bullet, she is beautiful, and you are Dr. Roz, he is tall" (p. 84). The children decide to get rid of Chipo's stomach under "the mphafa" tree (p. 79) because it "has a nice big shade" (p. 79). I believe that trees are frequently employed in We need New Names to suggest interconnectedness between humans and nonhuman nature. It is the "mphafa" tree that provides he children with "a nice big shade" (p. 79) while trying to rescue Chipo from her stomach, it is the guava tree that feeds them and satisfies their hunger, it is the jacaranda tree under which the men's eyes "never lift from the draughts" (p. 1) and it is trees in general that provide the inhabitants of Paradise with shade and shelter after Operation Murambatsvina. Apparently, through writing We Need New Names, Bulawayo launches an ecofeminist attack on Operation Murambatsvina and the androcentric dualisms whose adverse effects fall disproportionately on black women and make their problems more acute. Her ecofeminist empirical claim is that black Zimbabwean females are the greatest sufferers who bear intolerable burdens in family sustenance amid such an environmental deterioration. 


\section{Conclusion}

Ecofeminism is a branch of feminism that sees the oppression of women and the domination of nature as inextricably interconnected. From its very beginning, Bulawayo's debut novel We Need New Names explored the relationships between human and nonhuman nature and revealed the serious damage done to the Zimbabwean environment through Operation Murambatsvina and the subsequent repression and degradation of the country's black females. In her novel, Bulawayo skillfully demonstrated the parallels between environmental deterioration and the oppression of women and connected social and political injustice with environmental issues in Zimbabwe. It was Darling, her mother and the other black females in particular who primarily felt the disastrous effects of Operation Murambatsvina. This monstrous operation created an unsustainable environment in which Zimbabwean females were vulnerable and humiliated, but they remained unable to resist the campaign because of their oppressive patriarchal political system. Narrated from a female point of view, the novel combined environmental issues and women's problems and provided Darling's female perspective regarding the unjustified patriarchal domination of women and nature in Zimbabwe.

Using the ecofeminist lens, this ecofeminist reading of Bulawayo's novel demonstrated how nature is a feminist issue in We Need New Names and exposed how patriarchal greed and maldevelopment policies are primarily responsible for the Zimbabwean females' plight at home since Operation Murambatsvina destroyed their environment, their well-being and their livelihoods. The study also illustrated how Zimbabweans' disconnection from their land, fictionalized through Darling's immigration to America, destroyed their sustainable lifestyles in their anti-immigrant environment. In addition, the article examined the link between the rape of the earth and the rape of women in Bulawayo's We Need New Names as portrayed through Chipo's rape and the sexual abuse of the two black girls. I ultimately conclude that Bulawayo should be considered as an ecofeminist author who sought to defend Zimbabwean woman and their environment against the androcentric dualisms and patriarchal conceptual frameworks that justifies the degradation of both women and nature. 


\section{Dr. Salman Mohammed Salama}

\section{References}

Bulawayo, N. (2014). We need new names: A novel. Back Bay Books.

Eaton, H., \& Lorentzen, L. A. (2003). Ecofeminism and globalization: exploring culture, context, and religion. Lanham, MD: Rowman \& Littlefield Publishers.

Gaard, G. C. (2010). Ecofeminism: women, animals, nature. Philadelphia: Temple University Press.

Glotfelty, C., \& Fromm, H. (2009). The ecocriticism reader: landmarks in literary ecology. Athens, Ga: University of Georgia Press.

Gray, E. D. (1981). Green paradise lost. Wellesley, MA: Roundtable Press.

King, Y. (1983). Toward an Ecological Feminism and a Feminist Ecology. In J. Rothschild (Ed.), Machina Ex Dea: Feminist Perspectives on Technology (pp. 118-129). Pergamon.

Merchant, C. (2012). Radical ecology: the search for a livable world. New York: Routledge.

Plumwood, V. (2002). Feminism and the mastery of nature. London: Routledge.

Plumwood, V. (2001). Nature as Agency and the Prospects for a Progressive Naturalism. Capitalism Nature Socialism, 12(4), 3-32. doi: 10.1080/10455750101245225

Ruether, R. R. (2002a). New woman, new earth: sexist ideologies and human liberation. Boston: Beacon Press.

Ruether, R. R. (1994). Gaia \& God: An ecofeminist theology of earth healing. San Francisco: HarperSanFrancisco.

Ruether, R. R. (2002b). Women Healing Earth: Third World Women on Ecology, Feminism, and Religion. Maryknoll (N.Y.): Orbis Books.

Seager, J. (2019). Earth Follies: feminism, politics and the environment. London: Routledge.

Shiva, V. (2014a). Close to home: women reconnect ecology, health, and development. London: Routledge. doi: https://doi.org/10.4324/9781315070452

Shiva, V., Mies, M. (2014b). Ecofeminism. United Kingdom: Zed Books.

Shiva, V. (2016). Staying alive: women, ecology, and development. Berkeley, CA: North Atlantic Books.

Warren, K. J. (2010). Ecofeminism: women, culture, nature. Bloomington: Indiana Univ. Press.

Warren, K. J. (2000). Ecofeminist Philosophy: A Western Perspective on What It Is and Why It Matters. Lanham,, Maryland: Rowman \& Littlefield Publishers. 